\author{
Aleksandra Banaszkiewicz \\ Uniwersytet Mikołaja Kopernika w Toruniu \\ e-mail: aleksandra.banaszkiewicz@umk.pl \\ ORCID: 0000-0002-8923-0771
}

\title{
DYDAKTYKA KSIĘGOWOŚCI \\ W SZKOLNICTWIE HANDLOWYM OKRESU \\ DWUDZIESTOLECIA MIĘDZYWOJENNEGO \\ W POLSCE
}

\section{DIDACTICS OF ACCOUNTING \\ IN COMMERCIAL SCHOOLS \\ OF THE INTERWAR PERIOD IN POLAND}

DOI: $10.15611 /$ pn.2018.522.15

JEL Classification: M41, B19

Streszczenie: Celem artykułu jest przedstawienie ogólnych zasad dydaktyki księgowości w okresie dwudziestolecia międzywojennego w Polsce. Jako przykład placówki wykładającej księgowość na poziomie akademickim posłużyło Wyższe Studjum Handlowe w Krakowie. Dążąc do realizacji celu artykułu, podjęto próbę uzasadnienia tezy, że zasady kształcenia w wyższej szkole handlowej okresu międzywojennego w Polsce dawały możliwość dobrego przygotowania do wykonywania zawodu księgowego na szczeblu kierowniczym. W celu uzasadnienia sformułowanej tezy przeprowadzono badania empiryczne o charakterze archiwalnym obejmujące literaturę omawianego okresu. Przedstawione w artykule wyniki badań uzasadniają postawioną w nim tezę. Prezentowane w ramach przedmiotu księgowość treści programowe, skoncentrowane wokół praktycznej ewidencji zdarzeń księgowych, uzupełniały dodatkowe przedmioty, dzięki którym absolwent szkoły zyskiwał szeroką wiedzę ekonomiczną oraz umiejętność skutecznego zarządzania jednostką gospodarczą.

Słowa kluczowe: historia rachunkowości, dydaktyka księgowości, szkoły handlowe okresu dwudziestolecia międzywojennego.

Summary: The aim of the article is to present the general principles of accounting didactics during the interwar period in Poland. Wyższe Studjum Handlowe in Krakow was given as an example of an institution teaching accounting at the academic level. Aiming to achieve the purpose of the article, an attempt was made to justify the thesis that the principles of education at the high commercial school of the interwar period in Poland gave the opportunity to prepare well for the job of an accountant at managerial level. In order to justify the thesis formulated, empirical studies covering the literature of the discussed period were carried out. The research results presented justify the thesis put in it. The program content of the subject 
called accounting was concentrated around the practical record of accounting events. They were supplemented with additional items, thanks to which the graduate of the school gained broad economic knowledge and the ability to effectively manage an economic unit.

Keywords: accountancy history, didactics of accounting, commercial schools of the interwar period.

\section{Wstęp}

Dwudziestolecie międzywojenne to niezwykle istotny okres w historii naszej ojczyzny. Po ponadstuletniej niewoli państwo polskie stanęło przed wyzwaniem odbudowy kraju, w tym również jego gospodarki. Wieloletni podział na trzy zabory doprowadził do znacznego zróżnicowania pod względem ekonomicznym. Istotnym problemem była inflacja oraz brak kapitału i inwestycji. Wzrost cen wpłynął negatywnie na rozwój przedsiębiorstw, a w efekcie przerodził się w hiperinflację i załamanie gospodarki. Kondycję ekonomiczną Polski miały uratować zapoczątkowane w 1924 roku reformy Władysława Grabskiego. W latach 1926-1929 sytuacja gospodarcza uległa poprawie, a polski złoty stał się jedną z najbardziej stabilnych walut europejskich. Niestety, światowy wielki kryzys zahamował dalszy rozwój ekonomiczny naszego kraju. Jego negatywne skutki były odczuwane aż do 1935 roku. Tuż przed wybuchem II wojny światowej powstał projekt budowy Centralnego Okręgu Przemysłowego w widłach Wisły i Sanu. Istotnym działaniem było także przedstawienie przez ministra Eugeniusza Kwiatkowskiego wieloletniego programu gospodarczego [Skodlarski 1995].

Druga i trzecia dekada XX wieku to również czas, w którym zaczęto rozwijać w Polsce poszczególne gałęzie gospodarki, w tym handel i przemysł. Przedsiębiorstwa poszukiwały zatem odpowiednio wykształconych ludzi, którzy byliby w stanie sprostać obowiązkom zawodowym i jednocześnie posiadających odpowiednią ku temu wiedzę i kwalifikacje. Zaszłości historyczne spowodowały jednak ich brak na rynku pracy. Przed koniecznością zdobycia odpowiednich kompetencji stawali też często sami przedsiębiorcy, chcący sprostać wyzwaniu kierowania jednostką gospodarczą. Istotnymi elementami wymagającymi odbudowy w niepodległej Polsce były zatem oświata i nauka. Czyniono więc wysiłki ukierunkowane na stworzenie wydajnego systemu edukacji, także w odniesieniu do nauczania w zakresie nauk ekonomicznych.

Celem artykułu jest przedstawienie ogólnych zasad dydaktyki księgowości w okresie dwudziestolecia międzywojennego w Polsce. Przedmiot o nazwie księgowość był nauczany w tym czasie na różnych szczeblach edukacji w ramach szkół handlowych oraz na różnego rodzaju kursach dokształcających. W artykule uwaga została skoncentrowana na podejściu do nauczania księgowości na szczeblu wyższym. Jako przykład placówki wykładającej księgowość na poziomie akademickim posłużyło Wyższe Studjum Handlowe w Krakowie. Szkoła ta przygotowywała do 
praktyki gospodarczej osoby mające pracować na szczeblach kierowniczych bądź też samodzielnych przedsiębiorców. Dążąc do realizacji celu artykułu, podjęto próbę uzasadnienia tezy, że zasady kształcenia w wyższej szkole handlowej okresu międzywojennego w Polsce dawały możliwość dobrego przygotowania do wykonywania zawodu księgowego na szczeblu kierowniczym. W celu uzasadnienia sformułowanej tezy przeprowadzono badania empiryczne o charakterze archiwalnym obejmujące literaturę omawianego okresu. Niezwykle cennym źródłem wiedzy, obok książek wydanych w tym czasie, okazały się artykuły zamieszczone w $\mathrm{Cza}$ sopiśmie Księgowych $w$ Polsce oraz w periodyku wydawanym w pierwszych latach działalności studium pod nazwą Wiedza handlowa, miesięcznik poświęcony nauce i nauczaniu handlowemu oraz organ Wyższego Studjum Handlowego w Krakowie.

Realizacji wskazanego celu oraz uzasadnieniu tezy artykułu podporządkowano jego konstrukcję obejmującą części dotyczące szkolnictwa handlowego w Polsce, zasad funkcjonowania Wyższego Studjum Handlowego w Krakowie oraz przyjętych w omawianym okresie wytycznych co do nauczania księgowości.

Temat rachunkowości okresu dwudziestolecia międzywojennego, przede wszystkim pod kątem dorobku naukowego teoretyków rachunkowości, jak też stosowanych w tamtym czasie jej zasad był poruszany w pracach takich autorów, jak między innymi: M. Frendzel, A. Jaruga, A. Szychta [2004]; A. Grzegorek [2004]; S. Hońko [2003]; E. Pogodzińska-Mizdrak [2003]; E. Walińska [2004]; A. Banaszkiewicz [2013]; S. Jędrzejewski, M. Urbaszek, M. Kowalczyk [2017]. Mniej jest natomiast prac dotyczących samego procesu dydaktycznego, analizowanego na podstawie materiałów źródłowych. Niniejsza publikacja może stanowić dopełnienie treści prezentowanych w artykułach T. Sobczaka [2008] oraz S. Hońki [2008].

\section{Szkolnictwo handlowe w okresie międzywojennym w Polsce}

Po zakończeniu pierwszej wojny światowej władze polskie przejęły od zaborców szkolnictwo handlowe. W 1918 roku przy Ministerstwie Wyznań Religijnych i Oświecenia Publicznego powstała Sekcja Szkolnictwa Zawodowego. Sekcja ta, w celu ustalenia programów i typów szkół handlowych, zwróciła się o pomoc do kupców, przemysłowców i pedagogów. W drodze konsultacji ustalono, że przede wszystkim potrzebne są szkoły krótkoterminowe, dające wykształcenie w ciągu 2-3 lat. „Istnienie szkół fachowych krótkoterminowych jest dobrodziejstwem dla społeczeństwa, zwłaszcza dla klas niezamożnych, które wobec trudnych warunków ekonomicznych, nie zawsze są w możności kształcić dzieci przez długie lata w szkołach ogólnokształcących" [Byszewski 1925, s. 55]. W ciągu pierwszych sześciu powojennych lat założono osiem nowych państwowych szkół handlowych oraz bazując na współpracy z różnego rodzaju organizacjami, takimi jak na przykład Stowarzyszenie Kupiectwa Polskiego, rozwinięto sieć szkół handlowych. Podsumowując, należy stwierdzić, że w okresie tym liczba szkół handlowych wzrosła z 30 do 87 [Byszewski 1925, s. 58]. 
Spośród działających w okresie dwudziestolecia międzywojennego szkół handlowych na szczególną uwagę zasługują takie placówki, jak: Wyższa Szkoła Handlowa w Warszawie, Państwowa Szkoła Ekonomiczno-Handlowa we Lwowie, Wyższa Szkoła Handlu Zagranicznego we Lwowie, Szkoła Ekonomiczno-Handlowa w Krakowie oraz Wyższe Studjum Handlowe w Krakowie.

Najstarszą polską uczelnią handlową była założona w 1875 roku w Warszawie Szkoła Handlowa Leopolda Kronenberga. Szkoła ta funkcjonowała z przerwą między rokiem 1900 a 1905, po czym wznowiła działalność jako Wyższe Kursy Handlowe, a ostatecznie w 1915 roku przyjęła nazwę Wyższej Szkoły Handlowej mającej uprawnienia wyższego zakładu naukowego z prawami (od 1924 roku) szkół akademickich państwowych, w tym z możliwością nadawania stopni naukowych [Scheffs 1930, s. 2].

Państwowa Szkoła Ekonomiczno-Handlowa we Lwowie rozpoczęła działalność w 1899 roku jako Państwowa Wyższa Szkoła Handlowa. W następnych latach jej nazwę zmieniano dwukrotnie: najpierw na C.K. Akademię Handlową, a następnie na Państwową 4-letnią Szkołę Handlową. W skład działającej od 1925 roku Państwowej Szkoły Ekonomiczno-Handlowej we Lwowie wchodziły takie jednostki edukacyjne, jak [Scheffs 1930, s. 2-3]:

- Szkoła Ekonomiczno-Handlowa (4-letnia),

- Kurs Abiturientów Szkół Średnich (jednoroczny),

- Liceum Handlowe Koedukacyjne (2-letnie),

- Szkoła Handlowa Dokształcająca (3-letnia).

W 1922 roku we Lwowie, na wzór szkoły wiedeńskiej, założono Wyższą Szkołę Handlu Zagranicznego. Jej celem było kształcenie specjalistów w zakresie handlu zagranicznego i służby konsularnej [Scheffs 1930, s. 2-3].

Szkoła Ekonomiczno-Handlowa w Krakowie przyjęła nazwę w 1925 roku, przy czym swoją działalność rozpoczęła w 1882, zmieniając w międzyczasie nazwę trzykrotnie, ze Szkoły Handlowej na Wyższą Szkołę Handlową, a następnie na C.K. Akademię Handlową. Od 1925 roku w jej skład wchodziło wiele szkół średnich, szkół dokształcających oraz kursów wieczorowych, takich jak [Scheffs 1930, s. 2-3]:

- Szkoła Ekonomiczno-Handlowa Męska (4-letnia),

- Szkoła Ekonomiczno-Handlowa Żeńska (4-letnia),

- Szkoła Handlowa Męska (3-letnia),

- Szkoła Handlowa Żeńska (3-letnia),

- wieczorny kurs handlowy dla dorosłych (roczny),

- wieczorne kursy księgowości dla dorosłych (półroczne).

Charakter szkoły akademickiej miało natomiast powstałe w 1925 roku Wyższe Studjum Handlowe. Szkoła pod tą nazwą funkcjonowała do roku 1938, kiedy to została przekształcona w Akademię Handlową w Krakowie. 


\section{Wyższe Studjum Handlowe w Krakowie}

Zgodnie ze statutem Wyższe Studjum Handlowe w Krakowie miało charakter szkoły akademickiej, ukierunkowanej na przekazywanie wiedzy i umiejętności handlowych o charakterze ogólnym. W myśl artykułu 4 statutu każdy profesor i wykładający miał prawo ,podawania i oświetlania z katedry według swojego naukowego przekonania i sposobem naukowem wszelkich zagadnień wchodzących w zakres gałęzi wiedzy, której się poświęca, ma on taksamo [pisownia oryginalna] swobodę w wyborze metod wykładów i ćwiczeń". Władze zwierzchnią nad studjum sprawował Minister Wyznań Religijnych i Oświecenia Publicznego, natomiast w skład władz wewnętrznych wchodziło kuratorium Wyższego Studjum Handlowego, grono profesorów, dyrektor i wicedyrektor [Bolland 1926a, s. 12].

Wyższe Studjum Handlowe w Krakowie powstało z myślą realizacji celów ukierunkowanych zarówno na praktykę, jak i teorię nauk handlowych. W odniesieniu do praktyki szkoła postawiła sobie dwa zadania, takie jak [Bolland 1926, s. 2]:

- wykształcenie na potrzeby rynku pracy czołowych pracowników mających wiedzę na temat nauk handlowych,

- wykształcenie osób zainteresowanych samodzielnym utworzeniem warsztatów pracy.

Realizacja celów naukowych miała z kolei przejawiać się wykonywaniem prac i badań z dziedziny handlowej oraz przygotowaniem nauczycieli towaroznawstwa na potrzeby szkolnictwa zawodowego [Bolland 1926, s. 2].

Najwyższą rangę przyznano zadaniu polegającemu na wychowaniu i kształceniu gospodarczo twórczych jednostek. Jego realizacja sprowadzała się przede wszystkim do nauki ,gospodarczego sposobu myślenia (...), który zdolny jest dostrzegać braki rodzimej produkcji i rodzimej organizacji handlowej i zauważać w zmieniających się ciągle w warunkach gospodarczych, społecznych i technicznych coraz to nowe, świeżo otwierające się możliwości pożytecznego działania" [Bolland 1926, s. 2]. Absolwenci Wyższego Studjum Handlowego w Krakowie mieli zgodnie z założeniami zasilić przede wszystkim szeregi samodzielnych przedsiębiorców w zakresie zarówno produkcji przemysłowej, jak i handlu o zasięgu międzynarodowym [Bolland 1926a, s. 2-3].

Realizacja postawionych celów wymagała doboru odpowiednich wykładów. W ich skład weszły zatem takie przedmioty, jak [Bolland 1926, s. 4]: organizacja handlu krajowego i międzynarodowego (część ogólna i część szczegółowa), arytmetyka handlowa, księgowość ogólna i szczegółowa, nauka o bilansach, handel jako czynnik twórczy produkcji, ekonomia, polityka handlowa, polityka bankowa, skarbowość, prawo międzynarodowe, prawo polityczne i administracyjne, encyklopedia prawa i prawo kupieckie, prawo wekslowe i czekowe, towaroznawstwo ogólne i szczegółowe. Wymienione powyżej wykłady uzupełniały ćwiczenia i seminarium z zakresu towaroznawstwa oraz takie przedmioty, jak: technika transportu handlowego, inicjatywa handlowa i przemysłowa wraz seminarium, psychologia pedago- 
giczna, dydaktyka towaroznawstwa, psychologiczne zadania reklamy, nauka o cle wraz taryfoznawstwem, języki obce: angielski, francuski i niemiecki oraz stenografia.

Przedstawiony powyżej plan wykładów dotyczył Wydziału Ogólno-Handlowego. W następnym roku działalności, czyli 1926/1927, oferta dydaktyczna została poszerzona o zajęcia na wydziale towaroznawstwa (Instytut Towaroznawczy) oraz o Studium Orjentalne.

Rok szkolny był podzielony na trzy trymestry, a tok edukacji obejmował trzy lata nauki. Podczas pierwszego roku przekazywano wiedzę dotyczącą podstawowych elementów nauk handlowych. Również rok drugi miał charakter teoretyczny i koncentrował się na pogłębieniu treści przekazanych wcześniej. Nie dawał jednak „ani specjalizacji, ani możliwości wdrożenia się do samodzielnej pracy [Bolland 1927a, s. 13], co było podstawowym celem roku trzeciego. Każdy rok szkolny kończył się egzaminami, a efektem końcowym nauki był egzamin dyplomowy.

Przedmiotem o priorytetowym znaczeniu było towaroznawstwo, o czym pisze Jan Krauze w następujących słowach [1927, s. 2]: „Kupiec dzisiejszy, wobec wzmożonej walki konkurencyjnej, musi znać gruntownie ten dział, w którem zamierza pracować, a więc to, co w obecnej terminologii nazywamy towaroznawstwem i to nie tylko ze strony opisowej, jak to miało miejsce dawniej, ale i ze strony fachowej, tzn. na podstawie analizy chemicznej i właściwości mechanicznych. Powinien znać warunki produkcji, a więc wszystkie czynniki prowadzące do umiejętności kalkulacji - a więc zasady gospodarki materiałowej, energetycznej, transportowej”.

Natomiast rangę księgowości wśród nauk wykładanych w szkołach handlowych podkreślał z kolei Marcel Scheffs, pisząc między innymi następujące słowa: „,...) znajomość nie tylko mechaniki i techniki księgowości ile analizy, syntezy i ducha jej jest nadzwyczaj ważnym czynnikiem naukowym, że wobec tego księgowość powinna znaleźć uznanie jako nauka o charakterze nauk wyższych na równi z botaniką, chemią, statystyką, a w każdym razie powinna stanowić przedmiot główny w naukach ekonomicznych (...)" [Scheffs 1930, s. 25].

W Wyższym Studjum Handlowym w Krakowie księgowość ogólna była realizowana na pierwszym roku, a liczba godzin w każdym trymestrze wynosiła 4 godziny tygodniowo. Podczas drugiego i trzeciego roku nauki wykładem została objęta księgowość szczegółowa w wymiarze 2 godzin tygodniowo. Dodatkowo na trzecim roku w semestrze II wykładano naukę o bilansach -3 godziny tygodniowo [Bolland 1926a, s. 5-6].

W gronie wykładowców znaleźli się między innymi [Bolland 1926, s. 4-5]: Arnold Bolland, Tomasz Lulek, Zygmunt Sarna oraz Albin Żabiński. Ten ostatni pełnił funkcje kierownika Katedry Księgowości oraz wicedyrektora uczelni. Jednocześnie był wykładowcą księgowości ogólnej i szczegółowej oraz arytmetyki handlowej. Jego zainteresowanie księgowością zaowocowało napisaniem następujących pozycji literaturowych z dziedziny rachunkowości: Ksiegowość spółdzielcza (1925), Tematy do księgowości (1922, 1926, 1928, 1929, 1931), Księgowanie kapitałów własnych (1939). Tomasz Lulek, profesor Uniwersytetu Jagiellońskiego, wykładał 
ekonomię, skarbowość, naukę o bilansach i politykę ekonomiczną. W jego dorobku naukowym można znaleźć między innymi następujące prace dotyczące rachunkowości: Teoretyczne podstawy księgowości kupieckiej (1920), Metodyczny podręcznik księgowości kupieckiej (1922), Waloryzacja bilansów (1925), Rewizja bilansów spółek akcyjnych (1937). Na uwagę zasługuje fakt jego zainteresowań problemami dydaktyki szkolnictwa handlowego, o czym świadczą jego następujące publikacje: O polska szkotę handlowa (Projekt organizacji średnich szkót handlowych) (1919, współautor H. Weight), Wykształcenie ekonomiczne w szkolnictwie średnim, zawodowym i ogólnym, Rola czynnika wiedzy ekonomicznej w szkolnictwie powszechnym („Pamiętnik I Zjazdu Ekonomistów Polskich”, 1930) oraz Zasady nauczania rachunkowości (1932).

$\mathrm{Z}$ chwilą rozpoczęcia działalności na zajęcia w Wyższym Studjum Handlowym w Krakowie zgłosiło się 221 spełniających wymagania kwalifikacyjne absolwentów szkół średnich. Tak liczna grupa osób zainteresowanych wynikała przede wszystkim z ograniczonej liczby ośrodków kształcących zgodnie z podanym zakresem oraz z dostrzeżenia przydatności tego typu edukacji przez samą młodzież, o czym pisze prof. dr Zygmunt Sarna w następujących słowach [1926, s. 11]: „Coraz silniej objawiająca się wśród naszej młodzieży dążność zdobycia praktycznej wiedzy, wiedzy zawodowej, jest pocieszającym objawem zrozumienia, iż tylko jednostki należycie przygotowane do obranych w życiu warsztatów pracy na polu gospodarczem mogą spełnić właściwie swój obowiązek. Nic więc dziwnego, iż rosnąca ciągle ilość szkół zawodowych zapełnia się ciągle młodzieżą".

Zdobyte w szkole handlowej umiejętności były w pełni adekwatne do wymagań stawianych przed szefem księgowości. Wymagano bowiem od niego nie tylko gruntownej znajomości buchalterii, ale również nauk ekonomicznych, prawa handlowego, wekslowego i czekowego, ustaw stemplowych i podatkowych oraz ustaw o różnych formach spółek [Baliński 1932, s. 342]. To na nim spoczywał obowiązek tworzenia bilansu stanowiącego podstawę analizy sytuacji finansowo-ekonomicznej jednostki gospodarczej. Jego jakość zależała właśnie od prawidłowości prowadzonego systemu księgowości. Z drugiej strony, wiedza wyniesiona ze szkoły handlowej umożliwiała dokonanie ogólnej oceny warunków gospodarczych oraz ekonomicznych relacji zachodzących w kraju i za granicą, co z kolei miało wpływ na prawidłowe przeprowadzenie analizy stanu przedsiębiorstwa [Scheffs 1930, s. 2].

\section{Dydaktyka księgowości}

W dwudziestoleciu międzywojennym rachunkowość, utożsamiana zresztą z księgowością, była traktowana jako przedmiot o charakterze czysto praktycznym. Marcel Scheffs zdefiniował ją jako wiedzę, która [1943, s. 13] ,ustala reguły i sposoby prowadzenia ksiąg handlowych, w których rejestruje się działania ekonomiczne, dokonywane przez przedsiębiorstwa zarobkowe”. Dzięki księgowości można zatem [Scheffs 1943, s. 13]: 
- określić sytuację majątkową i finansową przedsiębiorstwa,

- kontrolować posiadane zasoby majątkowe,

- określić wyniki gospodarcze przedsiębiorstwa.

Teoretycy rachunkowości badanego okresu zwracali przy tym uwagę na słuszność posługiwania się przede wszystkim księgowością podwójną. Tomasz Lulek podkreślił jej znaczenie w następujących słowach [Lulek 1920, s. 22] „Jeżeli zadaniem księgowości jest systematyczne wykazywanie wniesionych do przedsiębiorstwa kapitałów, dokonanych obrotów i osiągniętych wyników, to spełnia je całkowicie tylko księgowość podwójna". Podobny pogląd podzielał Franciszek Tomanek pisząc [1923, s. 13]: „Od księgowości wymaga się, aby w sposób systematyczny przedstawiała stan majątku, jego zmiany i wyniki tych zmian. Wymogom tym odpowiada w zupełności jedynie księgowość podwójna. Księgowość pojedyncza nie tworzy systematycznie zorganizowanej całości, nie daje automatycznej kontroli, wskutek czego nie daje gwarancji ani dokładności, ani poprawności".

W praktyce gospodarczej, zgodnie z przepisami prawa, pełną rachunkowość, przez którą rozumiano prowadzenie ksiąg, kalkulację i sprawozdawczość finansową były zobowiązane prowadzić wyłącznie duże przedsiębiorstwa przemysłowe. Natomiast inne podmioty gospodarcze miały do wyboru albo stosowanie księgowości pojedynczej, albo księgowość podwójną uproszczoną [Pogodzińska-Mizdrak 2003, s. 596]. W nawiązaniu więc do stosowanych rozwiązań praktycznych przedmiotem nauczania księgowości była jej odmiana zarówno pojedyncza, jak i podwójna.

W dydaktyce księgowości koncentrowano się głównie na podawaniu gotowych rozwiązań pasujących do określonych sytuacji praktycznych. W odniesieniu do nauki księgowości podwójnej ciągle jeszcze stosowano metodę personifikacji. Taką metodę stosował na przykład Witold Góra w swoim podręczniku z 1922 roku pod tytułem Podręcznik księgowości, tom II, księgowość podwójna. Świadczy o tym chociażby następujący cytat [1922, s. 3]: „Chcąc sobie uzmysłowić, w jaki sposób powinno się księgować na rachunkach księgowości podwójnej, możemy sobie pomyśleć, że każdy z tych rachunków jest rachunkiem osobowym pracownika, który zawiaduje danym składnikiem majątku".

Ówczesny stan rzeczy zmienił Witold Byszewski, autor pierwszego wydanego po polsku nowoczesnego podręcznika księgowości [Szymański 1984, s. 73]. Nowatorstwo wprowadzonych przez niego zmian sprowadzało się między innymi do odejścia od obowiązującej w szkołach metody personifikacji konta na rzecz opracowanej przez niego na podstawie rozwiązań amerykańskich metody bilansu. Jego zdaniem adept księgowości powinien nauczyć się podczas procesu zdobywania wiedzy rozumowania kategoriami rachunkowości, a nie posługiwania się gotowymi rozwiązaniami. Jak pisze Franciszek Tomanek [1933, s. 10]: „Szkoła, zwłaszcza handlowa, powinna szczególną uwagę zwracać, już od samego początku, nie na mechaniczne wypracowywania w księgowości, ale na rozumowe jej ujmowanie, a następnie umiejętność odczytywania cyfr i posługiwania się nimi w codziennym życiu praktycznem". Celem dydaktyki księgowości powinno być zatem wskazanie środków 
i sposobów, dzięki którym księgowość zostanie opanowana przez ucznia w sposób przystępny i szybki. Zasady jej nauczania Tomanek podzielił na ogólne i szczegółowe. Wśród zasad ogólnych znalazły się następujące zalecenia [Tomanek 1926, s. 2]:

1) oparcie procesu nauczania na materiałach źródłowych w postaci oryginalnych ksiąg, alegatów, bilansów oraz zestawień; każda szkoła handlowa powinna mieć w tym celu archiwa handlowe,

2) za główny sposób przekazywania treści programowych należy uznać wykład, podręcznik (wybrany tylko jeden) zaś ma znaczenie pomocnicze. Jego główne zastosowanie to powtórki i uzupełnienie wykładu; przy czym zadawanie rozdziałów uczniom celem ich pamięciowego wyuczenia się nie powinno mieć miejsca,

3) coroczne zmienianie treści zadań wykorzystywanych jako ćwiczenia rozwiązywane w domu i w szkole.

Zgodnie z zaleceniami szczegółowymi nauczanie księgowości powinno się rozpocząć od opanowania zasad księgowości kupieckiej, a dopiero po ich przyswojeniu wskazane jest przejście do księgowości bankowej, przemysłowej, rolniczej i kameralnej. Zdobywając wiedzę z księgowości kupieckiej, uczeń w pierwszej kolejności powinien poznać podstawowe pojęcia, znaczenie i cel księgowości, a następnie przejść do opanowania reguł księgowości pojedynczej, a przede wszystkim zasad sporządzania inwentarza, księgi kasy oraz księgi dłużników i wierzycieli. Przyswojenie księgowości podwójnej wymagało z kolei nauczenia się takich zagadnień, jak [Tomanek 1926, s. 3]:

- systematyka ksiąg (podział na księgi obrotowe, ogólne, obrotowe szczegółowe i pomocnicze),

- systematyka kont (podział na konta składników majątkowych oraz wkładek kapitałowych własnych i obcych oraz zasady księgowania),

- księgowanie metodą amerykańską wraz z zamknięciem kont,

- księgowanie metodą włoską wraz ze sporządzeniem bilansu próbnego i końcowego oraz zamknięciem kont księgi głównej,

- księgowanie metodą niemiecką wraz z bilansem zamknięcia i otwarcia,

- księgowanie „interesów komisowych, wspólnych, eskontowanie weksli i faktur oraz ksiąźkowanie własnego kapitału w spółkach i spółdzielniach",

- księgowanie metodą francuską wraz zamknięciem spółki i likwidacją przedsiębiorstwa.

Zdaniem Franciszka Tomanka nauka rachunkowości ma bardzo duży wpływ na kształtowanie charakteru i wyrabianie zalet osób zajmujących się księgowością. Uczy między innymi skrupulatności, punktualności, porządku czy pracowitości. $\mathrm{Z}$ drugiej strony rozwija również od strony intelektualnej, co można zilustrować następującym cytatem „Rachunkowość wyrabia w człowieku konieczność myślenia, zastanawia się nad każdym poszczególnym zjawiskiem, celem rozklasyfikowania przejawów życia gospodarczego. Ktoś, kto musi segregować jakieś fakty na poszczególne grupy, musi mieć zdolność wnikania w pewne więcej lub mniej charakterystyczne, cechy, aby na ich podstawie urobić sobie sąd o danem zjawisku i zaszeregować je tej a nie innej kategorii [Tomanek 1933, s. 78]. 
Proces dydaktyczny miały wspierać odpowiednie podręczniki. Ich autorami byli głównie wykładowcy poszczególnych uczelni. Do użytku szkolnego w latach dwudziestych ubiegłego stulecia stosowano na przykład powstałe dziesięć lat wcześniej książki autorstwa Witolda Góry. Popularnością cieszyły się również podręczniki Witolda Skalskiego. Wśród innych podręczników omawianego okresu warto wspomnieć prace Franciszka Tomanka, Zygmunta Iwaszkiewicza czy Witolda Byszewskiego.

Podręczniki zawierające treści teoretyczne z zakresu rachunkowości miały dwojaki układ. Część autorów przedstawiała w pierwszej kolejności zasady sporządzania inwentarza i bilansu, inni natomiast traktowali wywody na te tematy jako punkt kulminacyjny książki. Obie metody traktowano jako dobre, a użycie takiej, a nie innej warunkowane było przez odbiorcę. Ze względu na uczniów szkół i kursów handlowych wskazane było użycie metody pierwszej ,jako łatwiej przenikającej do umysłów jeszcze nieprzygotowanych", natomiast drugą metodę preferowano dla osób posiadających już wiedzę praktyczną z księgowości, a zainteresowanych jej usystematyzowaniem od strony teoretycznej (Czasopismo księgowych w Polsce 1928, s. 35). Przykładowo opracowane przez profesora akademii handlowej w Krakowie - Albina Żabińskiego, tematy do księgowości zawierały szereg ćwiczeń ułożonych w bloki tematyczne dotyczące zasad sporządzania inwentarza, prowadzenia dziennika oraz dokonywania zapisów ewidencyjnych w konkretnych księgach, takich jak na przykład księga dłużników i wierzycieli, towarowa czy też walut [Żabiński 1946]. Natomiast o przeznaczeniu swojego podręcznika z 1937 roku pod tytułem Temat do księgowości handlowej Marian Ratowski [1937, s. 1] pisze, że ma on za zadanie umożliwienie poznania najbardziej typowych dowodów księgowych, zobrazowanie szerokiego spektrum operacji gospodarczych występujących jednego dnia w przedsiębiorstwie czy też dostarczenie materiału dyskusyjnego.

W odniesieniu do kadry nauczycielskiej żywiono przekonanie o konieczności łączenia zajęć edukacyjnych z praktyką zawodową. Tym samym nauczyciel nie powinien być wyłącznie teoretykiem. Jako argument przemawiający za koniecznością godzenia zadań badawczo-teoretycznych z pracą zawodową podawano przede wszystkim tempo zmian życia gospodarczego. Przekazywanie treści teoretycznych z zakresu nauk handlowych powinno być zatem zawsze ilustrowane przykładami pochodzącymi z praktyki gospodarczej. „(...) praca w przedsiębiorstwie handlowem, stwarza w wypadkach niezmiernie licznych, wprost idealne warunki zebrania np. odpowiedniego materjału, potrzebnego następnie celem pogłębienia i należytego rozwinięcia pracy pedagogicznej. (...) Tak np. buchalterja, chociaż posiada bardzo dużo skomplikowanej teorji, jednak tylko teoretycznie sposobu księgowania podawać nie może. Wprawdzie fantazja ludzka nieraz godna jest podziwu, ale przecież nieżyciowo traktowane wykłady stanowić będą tylko niepotrzebny balast, a również cały szereg zapisów buchalteryjnych, które są wytworem fantazji nauczyciela, a które jako tematy miały być użyte, księgowane być nie powinny, ze względu na niemożliwość życiowego zastosowania" [Zbyszyński 1927, s. 140]. 
System szkolnictwa w zakresie księgowości wspierał również Związek Księgowych w Polsce. Z inicjatywy działającego przy nim Komitetu Naukowego zostały między innymi w roku 1926/1927 zorganizowane kursy rachunkowości dla buchalterów przysięgłych. Po ich ukończeniu można było wykonywać wolny zawód buchaltera przysięgłego, zajmującego się między innymi ekspertyzą sądową, prywatną i organizacyjną w zakresie księgowości. W zarządzie kursu znaleźli się Witold Góra, H. Sachs, K. Czerwiński, A. Górski, T. Kotowicz. Jednocześnie stanowili oni część kadry nauczycielskiej. Ułożony przez nich program studiów rozpisywał materiał na 8 miesięcy, od 1 listopada do 30 czerwca, dając w sumie 224 godziny wykładowe, czyli około 8 tygodniowo. Na kurs zgłosiło się prawie 200 słuchaczy, przy czym do zajęć zostały dopuszczone 72 osoby. Liczba miejsc była ograniczona z przyczyn organizacyjnych, a wybór kandydatów był podyktowany przede wszystkim ich wykształceniem i praktyką zawodową. Tylko około $1 / 3$ słuchaczy miała ukończone studia wyższe. Zajęcia odbywały się trzy razy w tygodniu, w godzinach wieczornych. Na przykład plan na listopad przewidywał naukę takich przedmiotów, jak: analiza bilansów, organizacja rachunkowości przedsiębiorstw ubezpieczeniowych, prawo handlowe, organizacja rachunkowości przedsiębiorstw przemysłowych, nauki ekonomiczne, podatek stemplowy [Czerwiński 1927, s. 332-333].

\section{Zakończenie}

W okresie dwudziestolecia międzywojennego księgowość początkowo była traktowana jako rodzaj rzemiosła czy też sztuka praktyczna, przede wszystkim ze względu na to, że składało się na nią szereg prac o charakterze mechanicznym, typu gromadzenie rachunków czy też wprowadzanie danych do ksiąg. Rola księgowego sprowadzała się w głównej mierze do sprawnego i poprawnego zapisania zgromadzonego materiału liczbowego w odpowiednio przygotowanych do tego księgach. Postęp technologiczny ułatwił wykonywanie powtarzalnych czynności i przyspieszył proces wprowadzania danych, dając tym samym cenny czas na działania wymagające kompetencji i doświadczenia. Z drugiej strony, dokonujący się w badanym okresie szybki rozwój cywilizacyjny spowodował powstanie działających na znaczną skalę podmiotów gospodarczych wymagających sporych umiejętności w zakresie organizacji i zarządzania. Dlatego z czasem zaczęto dostrzegać i doceniać wykonywane przez księgowych prace o charakterze twórczym, polegające na przykład na ocenie wartości poszczególnych pozycji bilansowych czy też analizie rentowności przedsiębiorstwa. Zawód księgowego przestał być postrzegany w kategorii rzemieślnika, stał się on człowiekiem mającym szeroką wiedzę z zakresu ekonomii, prawa i skarbowości. Jednocześnie i sama rachunkowość przestała być wyłącznie postrzegana jako „kronikarka przedsiębiorstw”, a stała się skutecznym narzędziem w procesie zarządzania. Wspieranie przez rachunkowość procesu zarządzania nie byłoby jednak możliwe bez usprawnień technicznych, dzięki którym stało się możliwe znacznie szybsze pozyskiwanie potrzebnych informacji. Radykalne zmiany w tempie i ja- 
kości pracy zaszły w momencie wprowadzenie do księgowości luźnych arkuszy i kart oraz przeorganizowaniu prac księgowych poprzez ich odpowiednie połączenie i mechanizację. Rozszerzenie roli i znaczenia księgowego w życiu przedsiębiorstwa nie było również możliwe bez odpowiednio skonstruowanego systemu nauczania zorganizowanego w różnego typu szkołach handlowych.

Przedstawione w artykule wyniki badań uzasadniają tezę, że zasady kształcenia w wyższej szkole handlowej okresu międzywojennego w Polsce dawały możliwość dobrego przygotowania do wykonywania zawodu księgowego na szczeblu kierowniczym. Prezentowane w ramach przedmiotu księgowość treści programowe, skoncentrowane wokół praktycznej ewidencji zdarzeń księgowych, uzupełniały dodatkowe przedmioty, dzięki którym absolwent szkoły zyskiwał szeroką wiedzę ekonomiczną oraz umiejętność skutecznego zarządzania jednostką gospodarczą we współczesnym mu świecie.

\section{Literatura}

Baliński W., 1932, Biuro wzorowe (organizacja pracy biurowej), Nakład i własność fundacji wieczystej im. Henryka Józefa Chankowskiego, Warszawa.

Banaszkiewicz A., 2013, Zasady inwentaryzowania i bilansowania $w$ dwudziestoleciu międzywojennym w Polsce-zarys problemu, Zeszyty Naukowe Rachunkowości, t. 70 (126), SKwP, Warszawa.

Bień W., 1964, 55 lat polskiego czasopiśmiennictwa z zakresu rachunkowości, Rachunkowość, nr $5(173$.

Bolland A., 1926, Cele, metody i wykonanie zadań Wyższego Studjum Handlowego w Krakowie, [w:] Wiedza handlowa, miesięcznik poświęcony nauce i nauczaniu handlowemu oraz organ wyższego studjum handlowego w Krakowie, nr 1-2, styczeń-luty, Kraków.

Bolland A., 1926a, Program wyktadów Wyższego Studjum Handlowego w Krakowie na rok naukowy 2-gi 1926/7, [w:] Wiedza handlowa, miesięcznik poświęcony nauce i nauczaniu handlowemu oraz organ wyższego studjum handlowego w Krakowie, nr 5-6, maj-czerwiec 1926, Kraków.

Bolland A., 1927, Cele i drogi Wyższego Studjum Handlowego w Krakowie, [w:] Wiedza handlowa, miesięcznik poświęcony nauce i nauczaniu handlowemu oraz organ wyższego studjum handlowego w Krakowie, nr 3-4, marzec-kwiecień 1927, Kraków.

Byszewski W., 1925, Rozwój szkolnictwa handlowego w Polsce, Książnica Atlas, Warszawa-Lwów.

Czerwiński K., 1927, Otwarcie kursów rachunkowości, Czasopismo Księgowych w Polsce, nr 11.

Frendzel M., Jaruga A., Szychta A., 2004, Zasady wyceny bilansowej w Polsce w okresie międzywojennym, [w:] M. Gmytrasiewicz i A. Karmańska (red.), Polska szkoła rachunkowości, SGH w Warszawie, Warszawa.

Góra W., 1922, Podręcznik księgowości, tom II, księgowość podwójna, Książnica Polska Towarzystwa Nauczycieli Szkół Wyższych, Lwów-Warszawa.

Grzegorek A., 2004, Witold Byszewski - buchalter, naukowiec i dydaktyk, [w:] M. Gmytrasiewicz, A. Karmańska (red.), Polska szkoła rachunkowości, SGH w Warszawie, Warszawa.

Hońko S., 2003, Znaczenie dorobku wybranych polskich teoretyków bilansowych okresu międzywojennego, Zeszyty Naukowe Rachunkowości, t. 13 (69), SKwP, Warszawa.

Hońko S., Zasady nauczania rachunkowości wedlug profesora Tomasza Lulka, Zeszyty Naukowe Rachunkowości, t. 44(100), SKwP, Warszawa.

Jędrzejewski S., Urbaszek M., Kowalczyk M., 2017, Ewolucja systemu rachunkowości polskiej w okresie dwudziestolecia międzywojennego, Wydawnictwo SIZ, Łódź. 
Krauze J., 1927, Dzisiejsze zadania Wyższego Studjum Handlowego, [w:] Wiedza handlowa, miesięcznik poświęcony nauce i nauczaniu handlowemu oraz organ wyższego studjum handlowego w Krakowie, nr 1-2, styczeń-luty 1927, Kraków.

Lulek T., 1920, Teoretyczne podstawy księgowości kupieckiej, Nakł. Księgarni J. Czerneckiego, Warszawa, Kraków.

Pogodzińska-Mizdrak E., 2003, Rachunkowość polska poczatku XX wieku na tle epoki (1900-1939), [w:] S. Sojak, (red.), Historia, współczesność i perspektywy rachunkowości w Polsce, Wydawnictwo UMK, Torun.

Ratowski M., 1937, Temat do księgowości handlowej, Księgarnia Wł. Wilak, Poznań.

Sarna Z., 1926, Walory przedmiotów zawodowych, [w:] Wiedza handlowa, miesięcznik poświęcony nauce i nauczaniu handlowemu oraz organ wyższego studjum handlowego w Krakowie, nr 1-2, styczeń-luty 1926, Kraków.

Scheffs M., 1930, Księgowość naukowo pojęta, Czasopismo Księgowych w Polsce, nr 1.

Scheffs M., 1943, Rozbiór bilansu III., stan prawny i finansowy, maszynopis, Poznań.

Skodlarski J., 1995, Zarys historii gospodarczej Polski do 1939 roku, PWN, Warszawa.

Sobczak T., Rachunkowość w szkolnictwie wyższym Polski międzywojennej, Zeszyty Naukowe Rachunkowości, t. 42(98), SKwP, Warszawa.

Szymański K.G., 1984, Historyczny rozwój myśli w zakresie teorii księgowości, Zeszyty Teoretyczne Rady Naukowej, tom VIII, Warszawa.

Tomanek F., 1923, Księgowość kupiecka - pojedyncza i podwójna, Lwów.

Tomanek F., 1926, Dydaktyka księgowości, Wiedza Handlowa, miesięcznik poświęcony nauce i nauczaniu handlowemu oraz organ Wyższego Studjum Handlowego w Krakowie, nr 3-4, Kraków.

Tomanek F., 1933, Wartość wychowawcza rachunkowości, Czasopismo Księgowych w Polsce, nr 3.

Walińska E., 2004, Bilans podatkowy i jego wpływ na bilans handlowy w polskiej szkole rachunkowości okresu międzywojennego - zarys problemu, [w:] M. Gmytrasiewicz, A. Karmańska (red.), Polska szkoła rachunkowości, SGH w Warszawie, Warszawa.

Zbyszyński Cz., 1927, Zagadnienie pracy nauczycielskiej w dziedzinie handlu, Czasopismo Księgowych w Polsce, nr 5.

Żabiński A., 1946, Tematy do księgowości część I, nakład własny, Kraków. 